\title{
Москва-Париж: параллели и перпендикуляры территориального планирования
}

\author{
А.В.Кузьмин, РААСН, Москва \\ Л.Я.Ткаченко, НИиПИ градостроительства, Москва
}

В последнее десятилетие во многих странах происходят существенные изменения в системе территориального планирования, трансформируются состав и содержание основных документов, появляются новые инструменты регулирования градостроительной деятельности по мере усложнения объектов управления. Наибольший интерес для российской градостроительной практики представляют последние изменения в системе территориального планирования во Франции. Франция, как и Российская Федерация, является президентской республикой и классической представительницей кодифицированного права.

В статье проводится сравнение состава и содержания современных документов территориального планирования Франции и России. Новый Парижский местный градостроительный план (2019) и схема регионального развития (SDRIF-2030) для региона Иль-де-Франс (2013) вместе с Законом о Большом Париже анализируются как примеры стратегий пространственного развития крупнейших столичных городов Европы, сопоставимых во многих отношениях с Москвой и Московской областью. Рассматриваются приоритетные направления и зоны городского развития крупнейших мегаполисов Европы (Москвы и Парижа), показывается растущее значение комплексного развития транспортной инфраструктуры и учёта экологических аспектов в обеспечении высокого уровня жизни населения.

Формирование и проведение сбалансированной градостроительной политики, основой которой является постоянный мониторинг: непрерывный технологический цикл обоснования, разработки, принятия, контроля реализации и актуализации документов территориального планирования - по-прежнему остаются главным вызовом современности.

Ключевые слова: Париж, Большой Париж, регион Ильде-Франс, Москва, Большая Москва, Московская область, пространственное развитие, система территориального планирования, городская среда.

\section{Moscow-Paris: Parallels and Perpendiculars of Spatial Planning}

\section{A.V.Kuzmin, RAACS, Moscow}

L.Ya.Tkachenko, Research Institute of Urban Planning, Moscow

Over the past decade, many countries have undergone significant changes in the system of territorial planning, the composition and content of the main documents are being transformed, new tools for regulating urban planning activities appear as management objects become more complex. The latest changes in the territorial planning system in France are of the greatest interest for Russian urban planning practice. France, like the Russian Federation, is a presidential Republic and a classic representative of codified law.

The article compares the composition and content of modern territorial planning documents in France and the Russian Federation. The new Paris Urban Local Plan (2019) and the regional development scheme (the SDRIF 2030) for Île-deFrance Region (2013) together with the Law on Greater Paris are analyzed as examples of spatial development strategies of the largest metropolitan cities of Europe comparable in many aspects to Moscow and Moscow region. The higher-priority directions and urban development zones of the largest European metropolitan areas (Moscow and Paris), the growing importance of the integrated development of the transport infrastructure and consideration of environmental aspects in providing high living standards for the population are considered.

Formation and implementation of balanced urban planning policy, the basis of which is continuous monitoring: a continuous technological cycle of justification, development, adoption, monitoring of the implementation and updating of territorial planning documents - remains one of the main challenges of our time.

Keywords: Paris, Greater Paris, Île-de-France Region, Moscow, Greater Moscow, Moscow Region, spatial development strategy, territorial planning system, urban environment.

Я хотел бы жить и умереть в Париже, если 6 не было такой земли - Москва.

В.В. Маяковский. Прощанье. 1925 год

В последнее десятилетие во многих странах происходят существенные изменения в системе территориального планирования, появляются новые инструменты регулирования градостроительной деятельности. Данные вопросы находят своё отражение и в материалах международных организаций. Программой $00 \mathrm{H}$ по населённым пунктам в 2016 году были опубликованы на русском языке «Международные рекомендации по городскому и территориальному планированию» [1], а в 2017 году Организацией экономического сотрудничества и развития (ОЭСР) был подготовлен информационный выпуск о системах планирования землепользования в 32-х странах - членах 0ЭСР [2].

На фоне вялотекущей дискуссии в российском сообществе проектировщиков, академиков архитектуры, новых молодых урбанистов, блогеров и колумнистов о генеральном плане 
города и возможной его замены мастер-планом нам представляется актуальным сравнить документы территориального планирования Москвы и Парижа. Такое сравнение двух столиц уже становится хрестоматийным, особенно в последнее годы, после принятия официальных решений об образовании в 2010 году «Большого Парижа» ${ }^{1}$ и расширении границ Новой Москвы в 2011-2012 годах (рис. 1, 2, 3, 4).

Ещё сто лет назад Москва и Париж были практически сопоставимы друг с другом по численности населения и размерам территории. В Париже в начале XX века была максимальная численность населения - 2,88 млн чел., а в Москве проживало 1,7 млн чел. При этом территория города Москвы на начало 1917 года равнялась 178,9 кв. км [4], а площадь Парижа была только 86,2 кв. км (без Булонского и Венсенского лесов), то есть почти в два раза меньше [5]. Вся последующая история градостроительного развития двух столиц демонстрирует постоянный рост численности населения и территории Москвы на фоне стабильных аналогичных показателей Парижа.

После мирового кризиса 1929 года, когда во Франции стали стремительно и хаотично разрастаться пригороды Парижа, специальным законом от 14 мая 1932 года было принято решение о разработке проекта обустройства Парижского региона, что и положило начало региональному градостроительному планированию. В 1934 году архитектор Генри Прост предложил первый план управления для Парижского региона [6] в масштабе 1:50000. В плане Проста уже были заложены основные принципы развития столичной агломерации: радиальные и орбитальные связи, элементы зонирования территории, выделение охраняемых зон и зон урбанизации (рис. 5). Именно план Проста обеспечил на перспективу высокую плотность уличной и магистральной сети.

Примерно в этот же период в 1931 году Москва была выведена из состава Московской области. По решению Пленума ЦК в Москве под руководством архитекторов В.Н. Семёнова и С.Е. Чернышёва были развёрнуты работы по подготовке первого в истории советской страны комплексного плана реконструкции столицы, который был принят в 1935 году (рис. 6).

Основой нового Генерального плана оставалась радиально-кольцевая структура. Намечался рост численности населения Москвы с 3,66 млн чел. в 1935 году до 5 млн чел. к 1960 году и увеличение более чем вдвое городской территории преимущественно в юго-западном и северном направлениях (с 285 до 600 кв. км). Для последующего сдерживания разрастания города было предложено организовать вокруг столицы в радиусе 10-километровый лесопарковый защитный пояс (ЛПЗП) - многофункциональную территорию с включением крупных лесных массивов как «резервуаров» чистого воздуха для города и местом отдыха для населения (рис. 7).

${ }^{1}$ Journal Officiel dela République Française - JORF nº128 du 5 juin 2010 page 10339 texte $n^{\circ}$ 2010-597 du 3 juin 2010 relative au Grand Paris/. URL: www.journal-officiel.gouv.fr
Впервые в Генеральном плане реконструкции Москвы 1935 года были комплексно рассмотрены вопросы перспективного

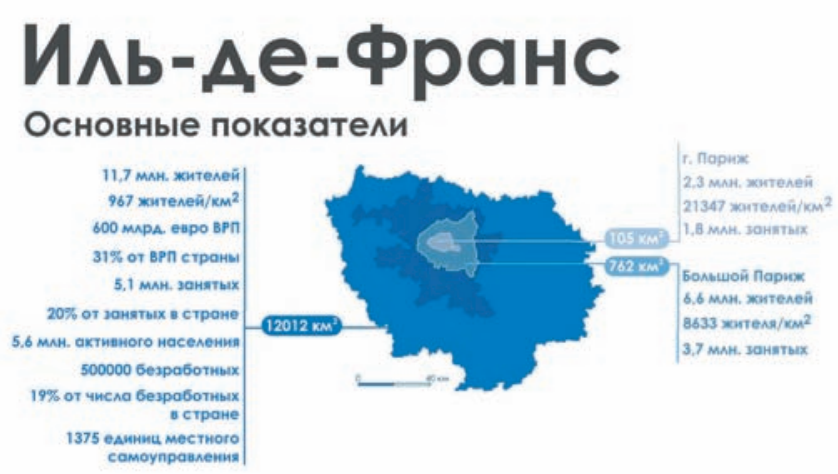

Рис. 1. Иль-де-Франс. Основные показатели [3]

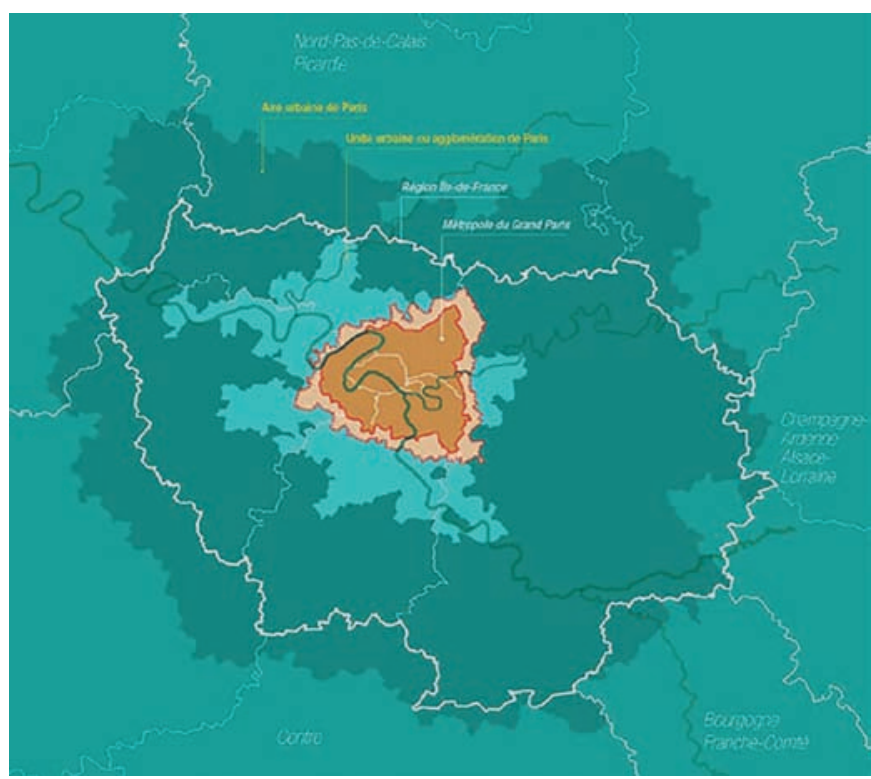

Рис. 2. Парижский регион, город, Большой Париж, агломерация [3]

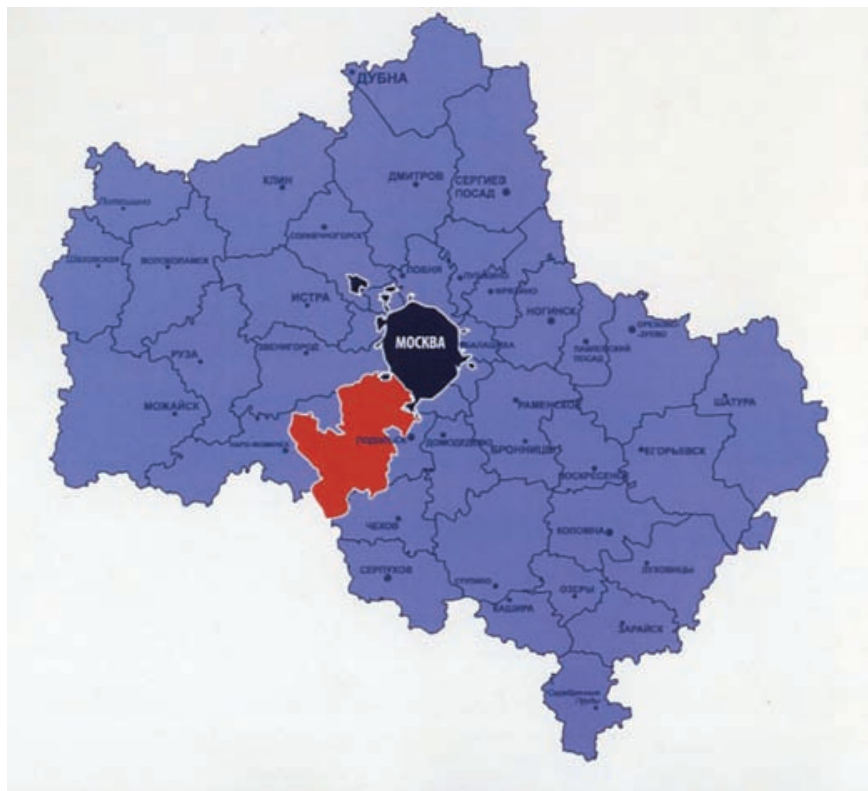

Pис. 3. Московская область и город Москва [4] 
развития Москвы и окружения столицы. Можно считать, что именно Генплан 1935 года положил начало градостроитель-

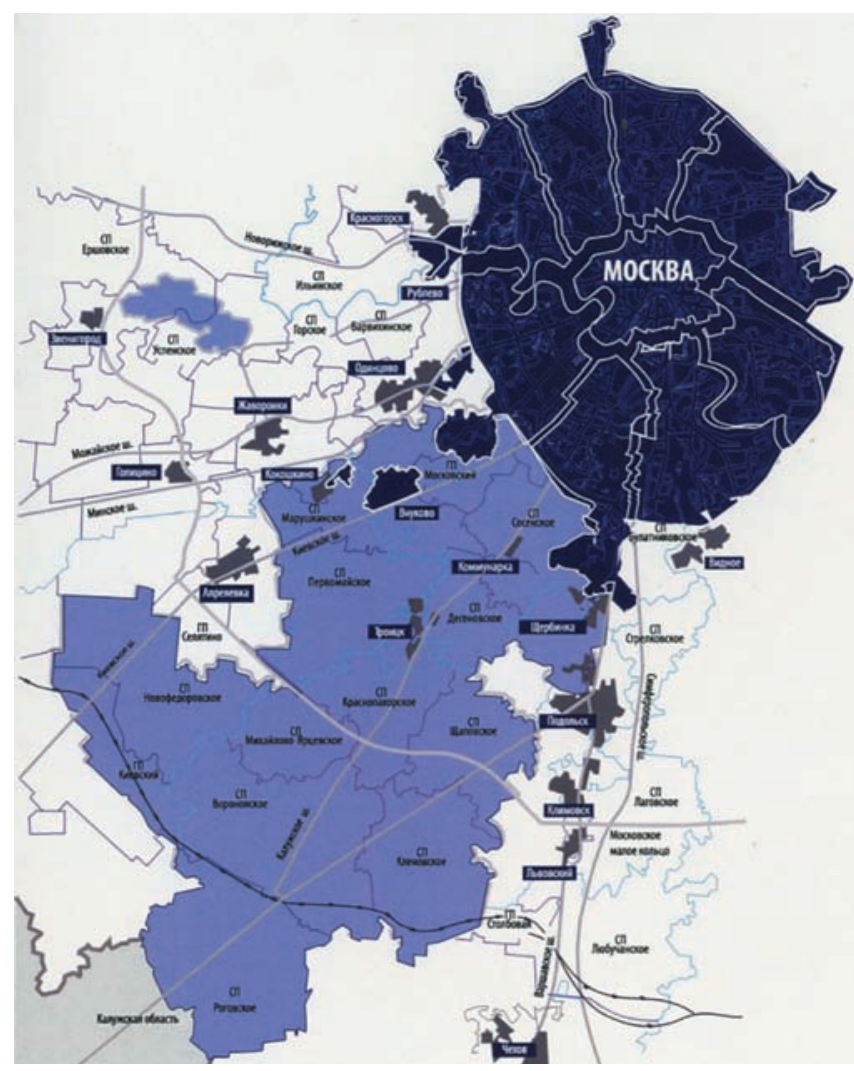

Рис. 4. Большая Москва [4]

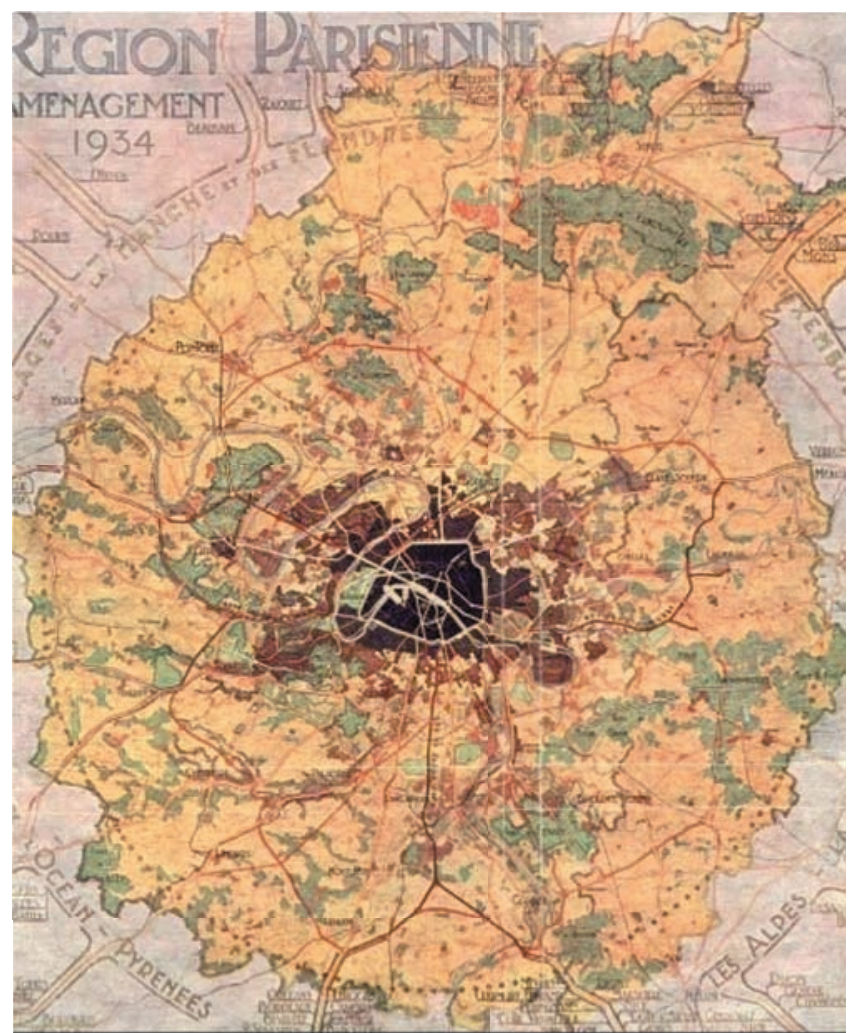

Рис. 5. Парижский регион по Генеральному плану Проста. 1934 год [6] ному взаимодействию города Москвы и Московской области и долгосрочному развитию систем метрополитена и железнодорожного транспорта, озеленения и обводнения города.

Французский опыт территориального планирования интересен для российской практики по ряду причин. Франция остаётся ярким примером страны с централизованно-бюрократической системой управления, Кроме того, Франция является классической представительницей кодифицированного права. В 1954 году впервые появляется Градостроительный кодекс Франции, а с 1956 года после образования регионов начинается и активное регулирование территориального развития. В рамках экономической концепции «полюсов роста» или «регионов-локомотивов» на юге страны развивались агломерации в противовес доминированию Парижского региона. Действовал запрет на строительство новых производств и объектов высшего образования в Париже и его пригородах, а из государственного бюджета выделялась финансовая поддержка различного вида тем предприятиям и фирмам, которые строили или расширяли свои производства в других регионах, создавая там новые рабочие места.

С 2000 года во Франции была изменена система стратегического территориального планирования. Для коммун как наименьшей территориальной единицы на смену планам землепользования пришли местные градостроительные планы (PLU), а для крупных городских агломераций была введена Схема территориального соответствия (SCOT) для координации различных отраслевых документов в области

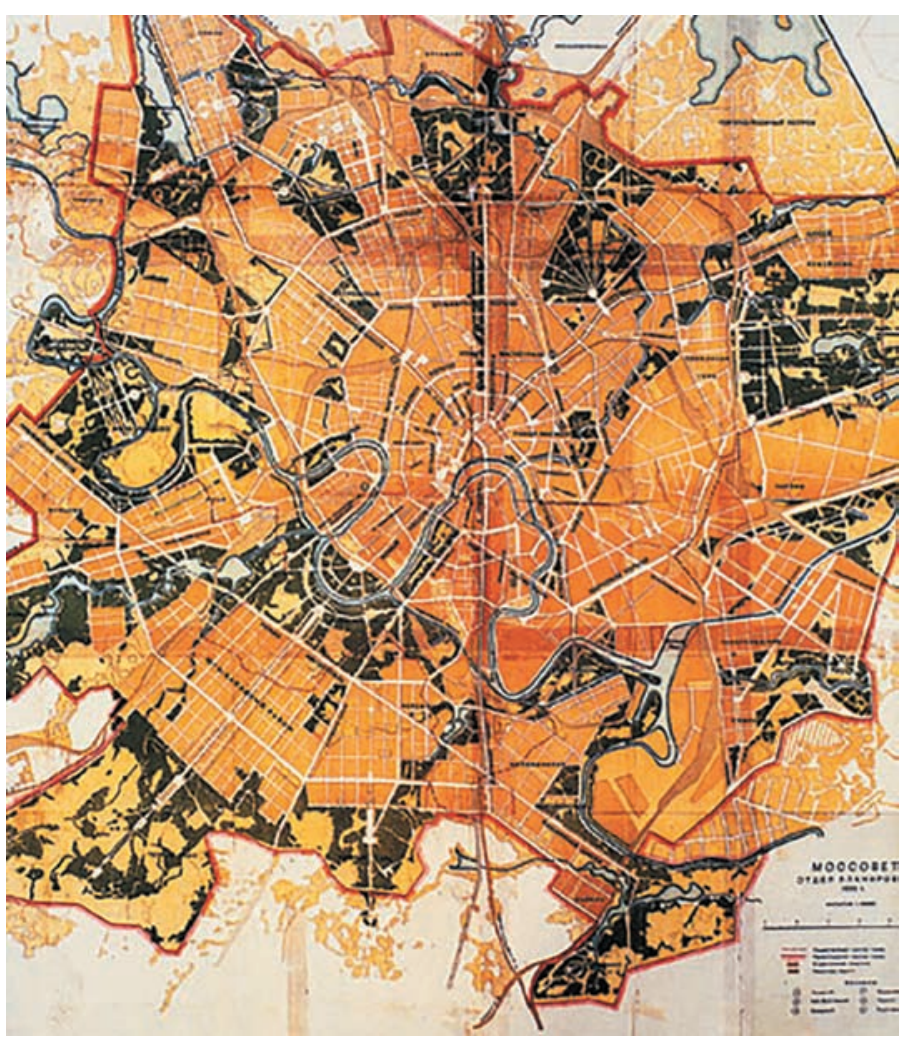

Рис. 6. Генеральный план реконструкции Москвы. 1935 год [4] 
транспорта, торговли, здравоохранения, среды обитания и экономики. Именно в Схеме впервые должен быть обоснован выбор пространственного развития территории.

Состав и содержание Схемы территориального соответствия определены Градостроительным кодексом Франции [7]. Содержание Схемы представляется в трёх частях:

1) презентационный отчёт, содержащий обоснование выбора устойчивого развития территории, диагностику с учётом экономического и демографического прогнозов, выявление сильных и слабых сторон, территориальных диспропорций в жилищном строительстве, развитии транспортной инфраструктуры и сферы услуг, а также развёрнутую экологическую оценку;

2) проект устойчивого развития и обустройства территории. Устанавливает цели городского планирования в сфере жилья и социального строительства, транспорта и передвижений, экономического развития, туризма и культуры, по районированию коммерческих и ремесленных учреждений, развитию электронных коммуникаций, сельского хозяйства, повышению качества ландшафтов, защите природных и лесных территорий, борьбе с разрастанием городов, сохранению и восстановлению экологической непрерывности, предотвращению природных катастроф и т.п.;

3) документ с основными направлениями и целями, в котором более детально отражаются ключевые направления обустройства территории, позволяющие реализовать проект устойчивого развития. В установках речь идёт о гармонизации развития таких сфер, как урбанизация и защита природных территорий и сельской местности, социальное жилищное строительство, окружающая среда, миграция населения, реализация коммерческих проектов и др.

В соответствии с ориентирами, установленными градостроительным проектом устойчивого развития, Схема определяет:

- основные направления пространственной организации и балансы между урбанизированными городскими пространствами и природными, сельскохозяйственными и лесными территориями;

- условия контролируемого городского развития и принципы реструктуризации урбанизированных пространств, оживления городских и сельских центров, въездов в город, охраны ландшафтов и предотвращения рисков.

Схема включает большое количество карт и схем, которые иллюстрируют все три её части, а также синтетическую итоговую схему «территориального соответствия».

При подготовке последующих документов (местных программ жилищного строительства, планов развития городской транспортной сети, схем размещения торговых объектов, местных градостроительных планов или карт коммун) должны быть учтены общие установки Схемы территориального соответствия. При этом подчёркивается, что во всех коммунах, расположенных на расстоянии менее чем 15 км от агломерации с населением более 50 тыс. жителей, ограничиваются права коммун в сфере градостроительной деятельности, если такая Схема не разработана.
Законодательство Франции обязывает проводить актуализацию схемы территориального соответствия не реже одного раза в десять лет, после чего она должна быть изменена или принята вновь в действующем варианте. При изменениях схемы необходима обязательная проверка на соответствие с другими градостроительными документами: программами местного жилищного строительства, градостроительными планами транспортных коммуникаций, местными градостроительными планами и т.д. Именно так формируют динамичную и взаимоувязанную совокупность градостроительных документов.

Для нового территориального образования «Большого Парижа» в настоящее время разрабатывается именно Схема территориального соответствия силами двух градостроительных организаций: Парижского ателье по градостроительству и Института «Париж-Регион».

Для города Парижа в 2019 году была утверждена третья редакция Местного градостроительного плана - PLU [8]. Первый Местный градостроительный план был принят только в 2006 году, хотя его подготовка велась с 2001 года. Разработка третьей редакции началась после представления доклада об итогах реализации за период с 2006 по 2015 годы. Новая версия Местного градостроительного плана учитывает изменения в законодательстве после 2012 года, в частности, необходимость отображения зелёного и голубого каркаса города (рис. 8, 9), а также приведение Плана в соответствие с Генеральной схемой региона Иль-де-Франс (SDRIF) на период до 2030 года.

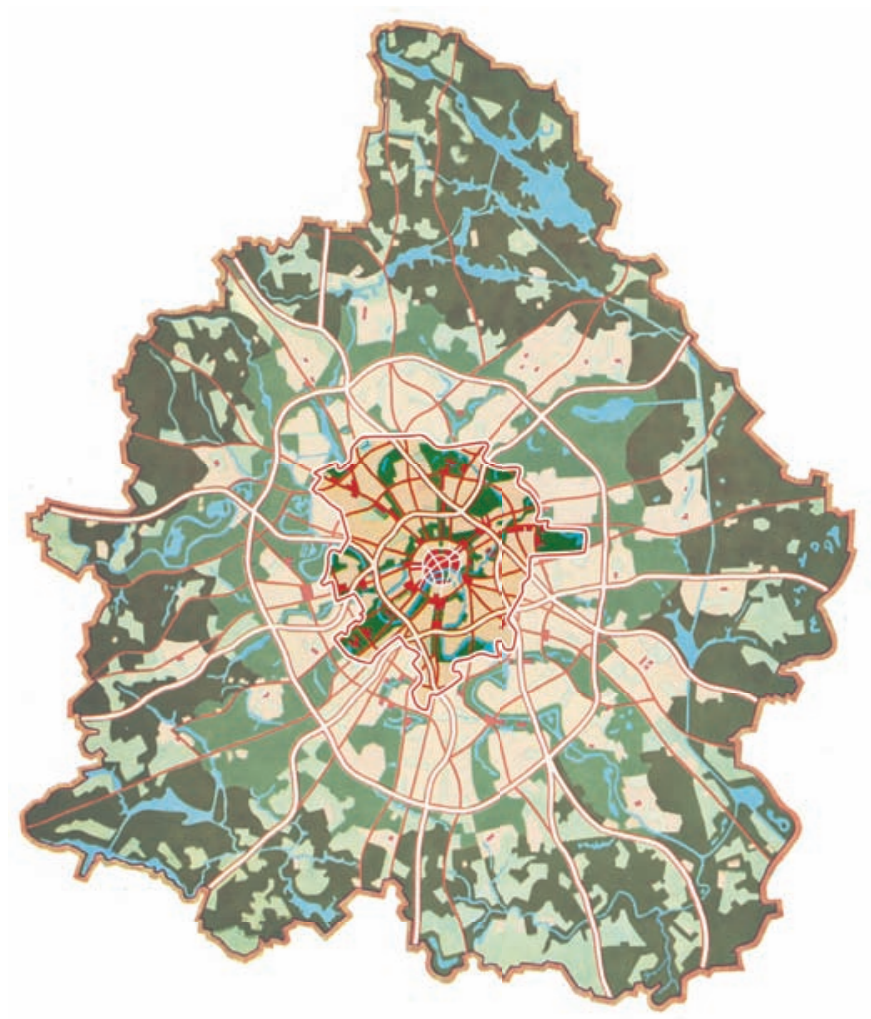

Рис. 7. Планировочная организация Москвы и её лесопаркового защитного пояса (ЛПЗП) [4] 
Новый План отвечает четырём политическим лозунгамзадачам: 1) доступ к жилью для всех; 2) биоразнообразие и природа в городе; 3) энергетический переход и адаптация территории к изменениям климата; 4) качество жизни и привлекательность.

PLU относится к стратегическим документам, которые определяют основные направления градостроительного развития города на 15 лет. Одновременно это и нормативный документ, так как регулирует изменения в парцелляции около 70 тысяч участков в городе, именно на его основе выдаются разрешения на строительство и снос объектов, регулируются функциональное назначение и режимы использования территории, а также высота зданий (рис. 10). PLU в Париже применяется на всей территории муниципалитета, за исключением трёх «белых пятен», для которых установлены свои правила охраны культурного наследия.

В презентационном отчёте Местного градостроительного плана Парижа для оценки современного состояния города используются многие показатели, больше внимания уделяется уровню развития социальной сферы (обеспеченность врачами, детскими дошкольными и школьными учреждениями), детальному анализу занятости и состояния жилищного фонда

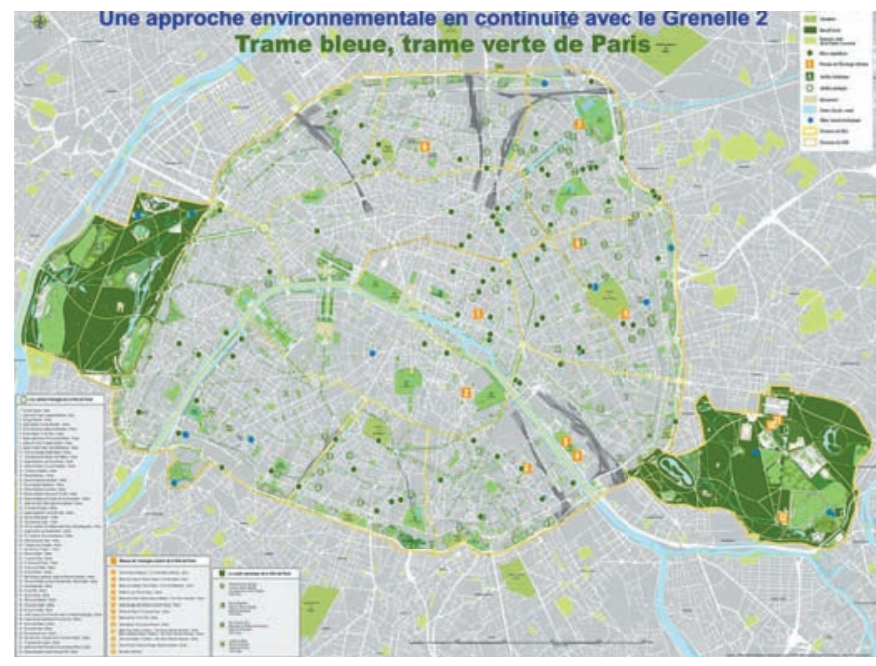

Рис. 8. Зелёный и голубой каркасы Парижа [9] в разрезе 20 округов для выявления основных территориальных диспропорций в городе.

Проект устойчивого развития и обустройства территории города Парижа сформирован вокруг следующих целевых задач:

1) улучшение условий жизни всех парижан (уменьшение повседневного загрязнения всех видов, защита новой концепции городских передвижений; создание новых зелёных зон; сохранение архитектурного и городского наследия);

2) расширение влияния Парижа и стимулирование создания мест приложения труда для всех (сбалансированная занятость по территории Парижа и создание новых экономических полюсов; развитие наиболее инновационных секторов экономики и новых форм и видов туризма; реализация крупных общественных объектов; создание условий для проведения крупных экономических, культурных и спортивных мероприятий).

3) сглаживание территориальных диспропорций (интеграция проблемных кварталов, внедрение новой жилищной политики, предлагающей больше социального разнообразия; создание различных объектов обслуживания и торговли по месту жительства);

4) привлечение партнёров для реализации Местного градостроительного плана (сотрудничество между коммуна-

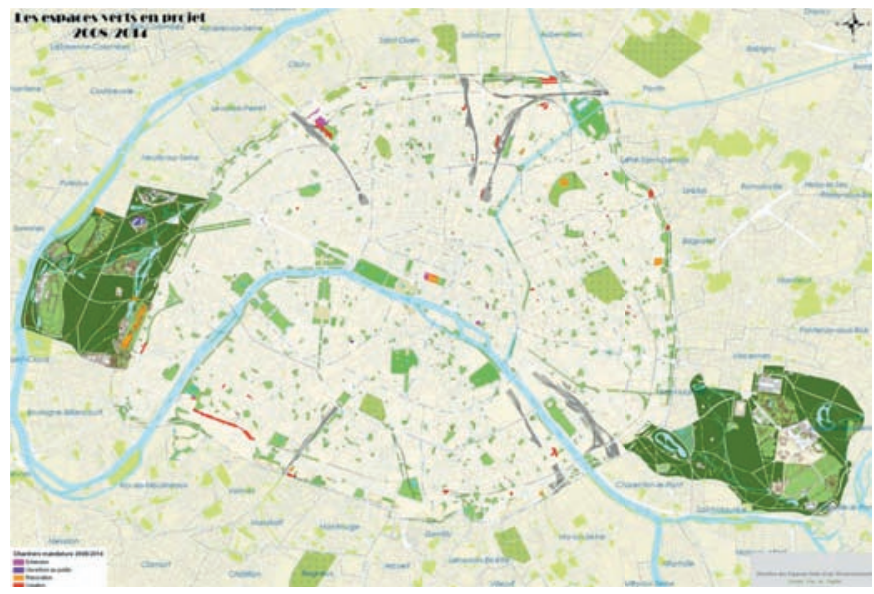

Рис. 9. Проектируемые зелёные пространства в 2008-2014 годы [9]

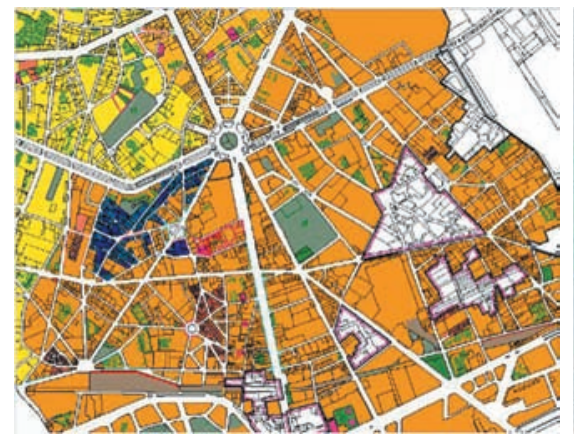

a)

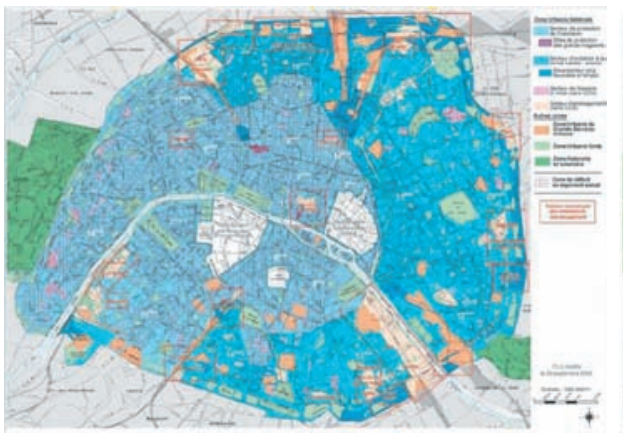

б)

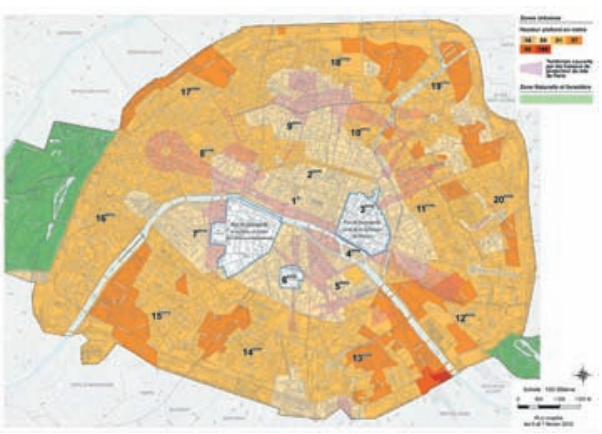

B)

Pис. 10. Местные градостроительные планы Парижа [ ]: а) функциональное зонирование; б) режимы использования; в) высотные регламенты 
ми, диалог и консультации с жителями и всеми партнёрами города).

Государственным советом Франции в декабре 2013 года была принята шестая Генеральная схема развития столичного региона на период до 2030 года (SDRIF-2030), которая отражает очередной этап градостроительного развития региона Иль-де-Франс (рис. 11). В соответствии с Градостроительным кодексом Франции SDRIF относится к специальному документу планирования, определяющему стратегию пространственной организации. Она направлена на управление городским и демографическим ростом и использование пространства с учётом обеспечения международного влияния этого региона. В ней указываются основные направления для сглаживания пространственных, социальных и экономических различий, для координации всех видов передвижений и сохранения сельских и природных территорий в целях обеспечения условий для устойчивого развития региона.

Эта схема определяет, в частности, назначение различных частей территории, мероприятия по защите и улучшению окружающей среды, местоположение основных видов транспортной инфраструктуры и крупных объектов обслуживания. Она указывает также направления расширения городских территорий, а также укрупнённые зоны размещения объектов промышленного, ремесленного, сельскохозяйственного и туристического назначения. SDRIF обеспечивает согласованность отраслевых государственных схем и планов и взаимодействие временных и пространственных аспектов планирования. Генеральная схема определяет стратегию обустройства территории региона в целом на двадцать лет с выделением ключевых приоритетов (рис. 12).

По Генеральной схеме численность населения в регионе к 2030 году может вырасти, согласно двум сценариям, до 12,4-13,4 млн человек, планируется создать более 600 тыс. новых мест приложения труда. В Генеральной схеме определены следующие главные цели [3]:

- обеспечение населения социальным жильём (1,5 млн социальных квартир до 2030 года, то есть строительство 70 тыс. квартир в год и доведение доли социального жилья в регионе до $30 \%)$;

- рост занятости и стимулирование экономической активности в регионе;

- развитие общественного транспорта (предусматривается строительство нового автоматического метро протяжённостью более 150 км с 57 новыми станциями) (рис. 13);

- сохранение природных ресурсов и обеспечение качества окружающей среды;

- обеспечение доступа к социально значимым объектам и службам, повышение качества социальной сферы.

SDRIF-2030 является иллюстрацией нового подхода к планированию, учитывающего различные пространственные уровни и временные шкалы: от видения региона до предложений по реализации; от диагностики до оценки обоснования.

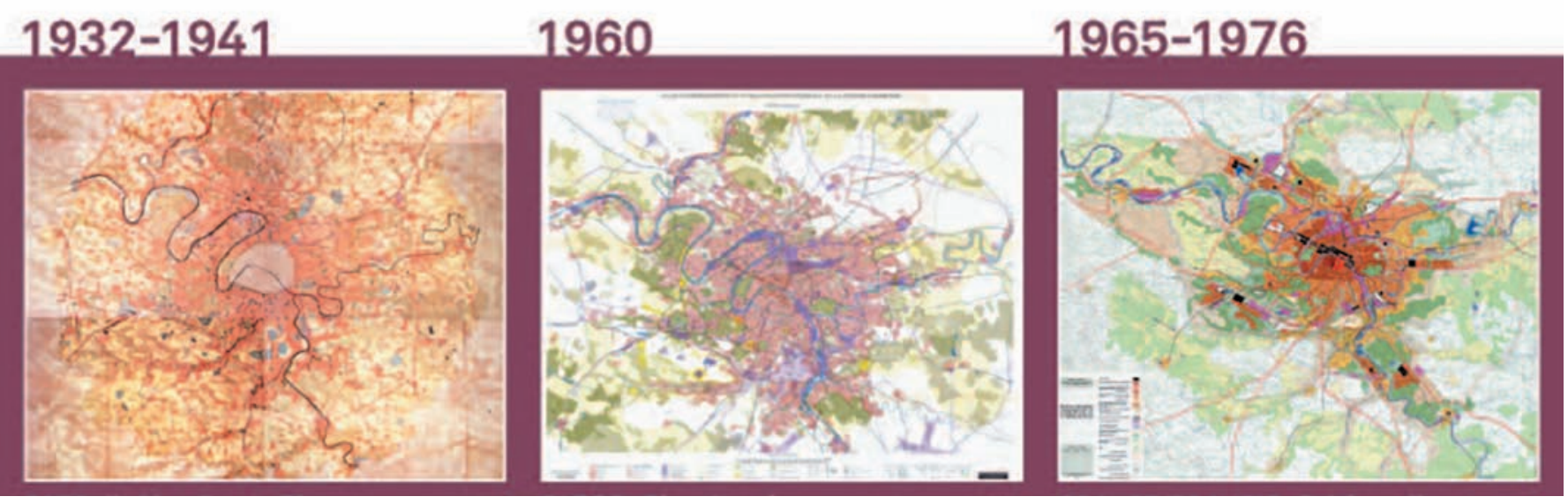

1994

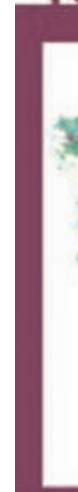

2008

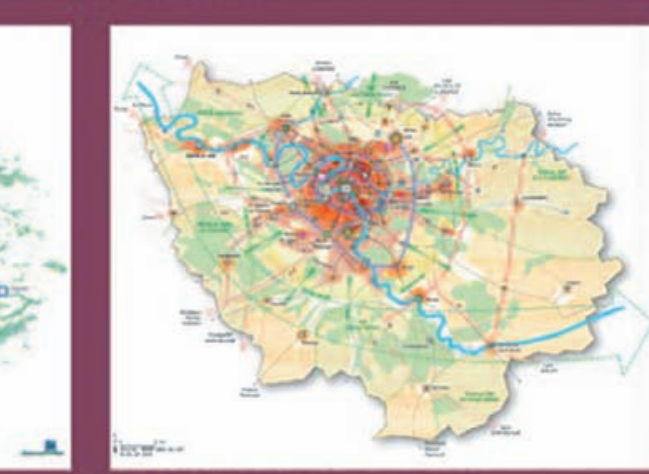

2013

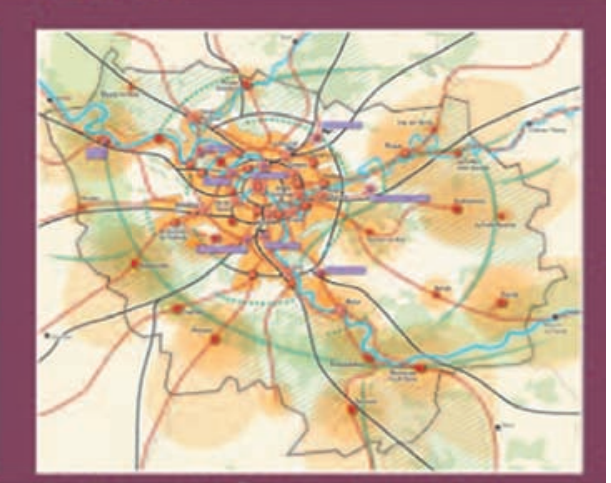

Рис. 11. Этапы градостроительного развития региона Иль-де-Франс [10] 
Для удобства чтения SDRIF-2030 была разбита на пять частей (хорошо иллюстрированных буклетов), которые, дополняя друг друга, образуют единое целое:

1. Региональное видение - это полностью иллюстрированное введение, в котором излагаются изменения в Парижском регионе и образе жизни его жителей, а также разнообразие ландшафтов и масштабы городского разнообразия в регионе;

2. Вызовы, проект пространственного развития и цели. В этой брошюре отражены цели и задачи регионального территориального планирования, стремление региона к устойчивому планированию и развитию в период до 2030 года в ответ на социальные, экономические и экологические вызовы. Основополагающими принципами развития региона являются: полицентризм, связь между городским планированием и развитием общественного транспорта с целью ограничения использования личных транспортных средств, более интенсивное использование городского пространства, социальная интеграция и разнообразие, контроль и защита сельскохозяйственных, природных и

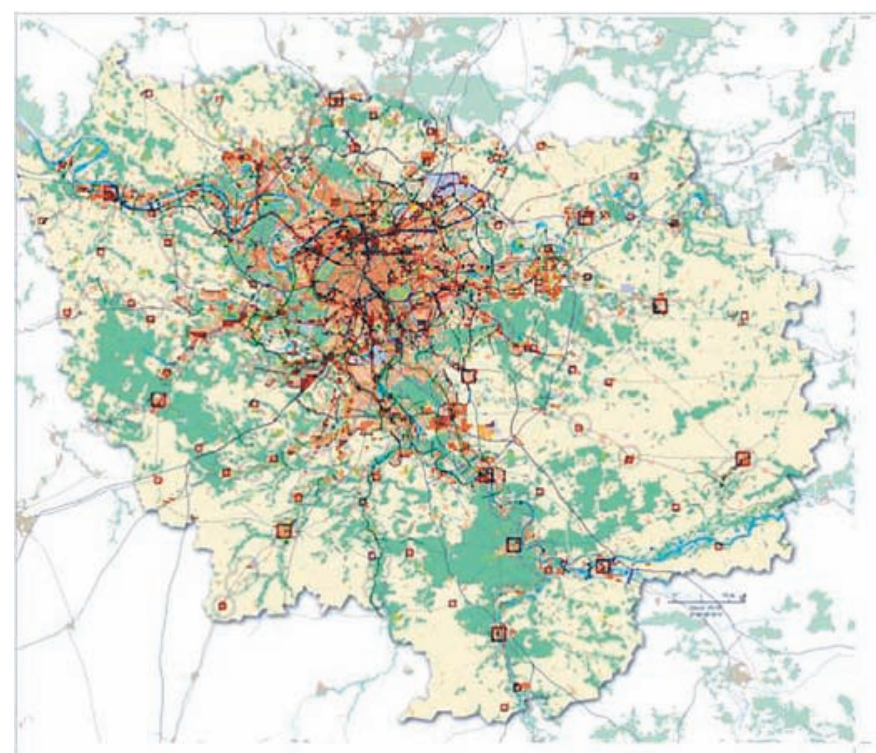

Рис. 12. Генеральная Схема региона Иль-де-Франс до 2030 года (2013) [3]

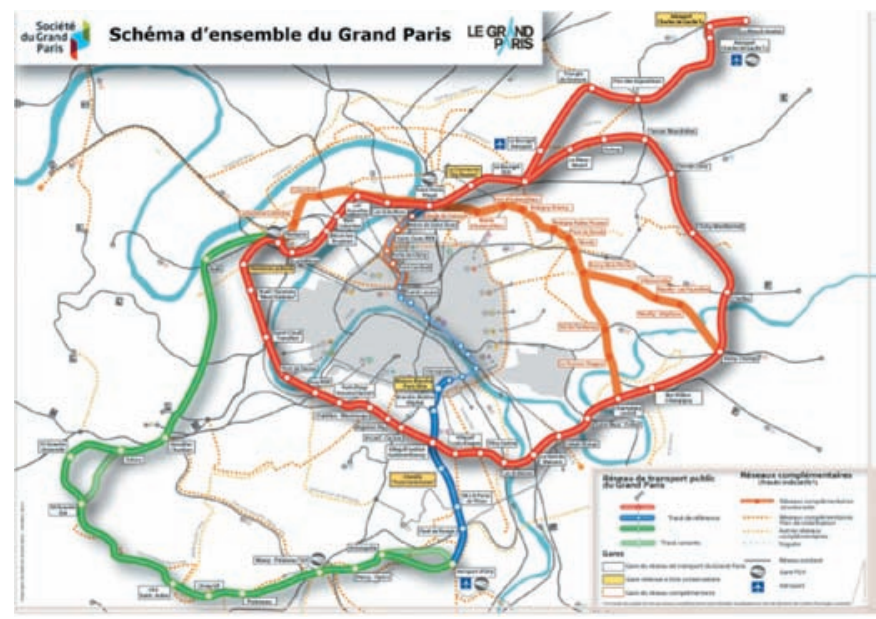

Рис. 13. Транспортная схема Большого Парижа [3] лесистых территорий. В ней также изложены направления деятельности для повышения привлекательности региона и поддержки жителей;

3. Основные регламентирующие направления и карта использования территории региона в масштабе 1:150000. В основных направлениях объясняются, на основе чего формируется пространственное развитие региона и как осуществляется взаимосвязь с городским планированием на уровне муниципалитетов и межмуниципальных образований;

4. Оценка состояния окружающей среды обосновывает и раскрывает варианты развития региона, направленные на создание благоприятных условий жизни населения и снижение эффектов негативного воздействия на окружающую среду;

5. Предложения по реализации, которые являются приложением к документу. В нём изложены различные государственные, партнёрские и договорные принципы взаимодействия, а также указаны организации и учреждения, которые

Таблица. Виды документов территориального планирования в Московском и Парижском столичных регионах (в соответствии с Градостроительным кодексом РФ и Градостроительным кодексом Франции)

\begin{tabular}{|c|c|c|c|c|}
\hline №Ne & $\begin{array}{c}\text { Административная } \\
\text { единица }\end{array}$ & $\begin{array}{c}\text { Площадь } \\
\text { территории, } \\
\text { кв.км }\end{array}$ & $\begin{array}{c}\text { Численность } \\
\text { населения, } \\
\text { млн чел. }\end{array}$ & $\begin{array}{c}\text { Документ территориального } \\
\text { планирования }\end{array}$ \\
\hline 1. & \multicolumn{4}{|c|}{ Парижский столичный регион (регион Иль-де-Франс) } \\
\hline 1.1 & Город Париж & 105,4 & 2,14 & $\begin{array}{l}\text { Местный градостроитель- } \\
\text { ный план (на 10-15 лет), } \\
\text { утверждён в 2006 г., с } \\
\text { изменениями в 2009, } 2012 \text { и } \\
2019 \text { rr. }^{2}\end{array}$ \\
\hline 1.2. & $\begin{array}{l}\text { Метрополия } \\
\text { «Большой Париж» }\end{array}$ & 814 & 7,2 & $\begin{array}{l}\text { Схема территориального } \\
\text { соответствия (на } 20 \text { лет), в } \\
\text { начальной стадии разра- } \\
\text { ботки }\end{array}$ \\
\hline 1.3. & Регион Иль-де-Франс & 12012 & 12,14 & $\begin{array}{l}\text { Генеральная схема (на } 20 \\
\text { лет) - SDRIF-2030, утвер- } \\
\text { ждена Госсоветом Франции в } \\
2013 \text { г. [11] }\end{array}$ \\
\hline 2. & \multicolumn{4}{|c|}{ Московский столичный регион (город Москва и Московская область) } \\
\hline 2.1. & Город Москва & 2561,5 & 12,6 & $\begin{array}{l}\text { Генеральный план города } \\
\text { Москвы (на } 20 \text { лет), утвер- } \\
\text { ждён Законом города Москвы } \\
\text { в } 2010 \text { г., с изменениями для } \\
\text { новой территории в } 2017 \text { г. }{ }^{4}\end{array}$ \\
\hline 2.2. & Московская область & 44329 & 7,6 & $\begin{array}{l}\text { Схема территориального } \\
\text { планирования (на } 20 \text { лет), } \\
\text { утверждена Правительством } \\
\text { Московской области в } 2007 \text { г., } \\
\text { с изменением в } 2018 \text { r. }\end{array}$ \\
\hline
\end{tabular}

${ }^{2}$ Le plan local d'urbanisme (PLU) version du 26/07/2019. URL: http:// pluenligne.paris.fr/plu/page/PLU?page_id=1.

3 Закон г. Москвы от 15 марта 2017 г. № 10 «0 внесении изменений в Закон города Москвы от 5 мая 2010 года № 17 "0 Генеральном плане города Москвы"» // Справочно-правовая система «Консультант Плюс». URL: http://www.consultant.ru/cons/cgi/online.cgi?req=doc; base=MLAW ;n=177073\#09314311657959959 (дата обращения: 17.08.2018).

4 Постановление Правительства Московской области от 11.07.2007 № 517/23 «0б утверждении Схемы территориального планирования Московской области - основных положений градостроительного развития» (с изменениями на 13 февраля 2018 г.)» // Справочно-правовая система «Консультант Плюс». URL: http://www.consultant.ru/cons/cgi/online.cgi?base=MOB\&n=52 594\&req=doc\#09157258852830781 (дата обращения: 20.08.2019) 
могут способствовать осуществлению проекта развития региона в соответствии с целевыми установками. Они также дают толкование того, как функционирует регион, определяя «территории столичных интересов».

Градостроительный кодекс Франции предписывает Региональному совету представить отчёт о реализации этой Схемы за шесть месяцев до истечения шести лет после даты утверждения Генеральной схемы региона Иль-де-Франс. После обсуждения этого отчёта на Региональном совете может быть принято решение о сохранении действующей Схемы, её частичной модификации, полном пересмотре или же об её отмене.

Обеспечение устойчивого развития региона требует контроля за реализацией Схемы с использованием пространственных, количественных и качественных данных. Реализация Схемы требует перевода её на уровень градостроительных документов местного уровня, а также учёта её предложений в рамках региональной и местной государственной политики при налаживании партнёрских отношений и сотрудничества на этой территории.

Проведённый анализ показывает условную возможность сопоставления города Москвы в новых границах лишь с регионом Иль-де-Франс, которые практически равны по численности населения, но по площади отличаются друг от друга почти в четыре раза. Следует заметить, что сегодняшняя метрополия Большого Парижа, например, по своим размерам абсолютно сопоставима с городом Москвой 1971 года, когда её площадь в административных границах равнялась 878,7 кв. км, а численность населения - 7,1 млн чел. По Генеральному плану города Москвы 1971 года для полицентричного развития предлагалось создать восемь планировочных зон со своими зональными центрами (рис. 14), увеличить протяжённость линий метрополитена на 190 км, а в Большом Париже планируется только на 150 км.

Практически же Париж сравним с Москвой лишь в границах Камер-Коллежского вала (площадью 71 кв. км), который был границей между городом и Московским уездом с 1864 года, или же с современным Центральным административным округом Москвы. Кстати, в 2001 году Правительством Москвы был утверждён проект градостроительного плана развития территории Центрального административного округа до 2020 года ${ }^{6}$, основные положения которого успешно реализуются и по сей день (организация пешеходных улиц и маршрутов, благоустройство территории, парковочные места, строительство жилья, десяти мостов и др.).

Наибольший интерес для анализа опыта территориального планирования Москвы представляет, на наш взгляд, Генеральный план столицы на период до 2020 года, одобренный в 1999 году правительством Москвы, а в 2005 году впервые

${ }^{6}$ Постановление Правительства Москвы от 24 апреля 2001 г. N 410-ПП «0 проекте градостроительного плана развития территории Центрального административного округа до 2020 года». URL: http://mosopen.ru/ document/410_pp_2001-04-24. его положения были утверждены законом города Москвы. Принятию этого Генерального плана предшествовало проведение комплекса НИР, которые затем послужили основой для разработки предложений по развитию и реорганизации производственных зон (1995), по развитию системы общегородских центров (1996), по основным направлениям сохранения и восстановления территорий природного комплекса (1997-1998). Кроме того, в 1996 году был подготовлен первый аналитический доклад о состоянии градостроительного развития Москвы, а в 1998 году - доклад о градостроительном развитии крупнейших столичных городов в сопоставлении с Москвой. В этом же году в Манеже была проведена первая выставка по материалам Генерального плана и важнейшим проектам, включая высотный комплекс Москва-Сити и др. Около 150 тысяч москвичей посетили Манеж, десятки тысяч оставили положительные отзывы.

В отличие от своих директивных предшественников этот генеральный план был документом принципиально нового типа. Это был регулятивный документ прогностического характера, направленный на координацию интересов и стимулирование активности в рамках общегородской стратегии развития. Генеральный план включал три части:

1. Основные направления градостроительного развития Москвы до 2010 года, отражающие цели, задачи и приоритетные направления развития города;

2. Градостроительное зонирование территории, устанавливающее рамочные условия использования территории, обязательные для всех участников градостроительной деятельности (функциональное, строительное и ландшафтное) (рис. 15).

3. Программу первоочередных градостроительных мероприятий на период до 2005 года, включая конкретные объёмы реконструкции и строительства жилья, развития транспортной, инженерной и социальной инфраструктур.

Важнейшим принципом, декларируемым в генплане, являлся приоритет экологических требований. Впервые в состав документа входила Схема комплексного благоустройства и эстетического оформления территории Москвы.

Более того, генеральный план был ориентирован на сложившуюся в то время в Москве трёхуровневую систему управления территориальным развитием и реализовывался посредством разработки градостроительных планов административных округов и районов города Москвы. В 2000-2005 годы были разработаны и утверждены градостроительные планы развития всех десяти административных округов и части районов города, около 20 территориальных и отраслевых схем, более 100 проектов планировки и межевания территорий. Ход реализации генплана ежегодно анализировался в режиме мониторинга. Аналитический доклад Москомархитектуры, подготовленный Институтом генплана Москвы, представлялся на рассмотрение правительству Москвы, а по результатам обсуждения принималось специальное постановление. 
По генеральному плану ведущей тенденцией территориально-отраслевого развития столицы являлся переход от экстенсивного развития, в том числе территориального роста, к структурной реорганизации как градообразующей базы, так и сложившейся территориальной организации. Однако многие показатели развития транспортной инфраструктуры на 2020 год не достигнуты до сих пор. Так, например, не удалось увеличить плотность улично-дорожной сети до 8 км на квадратный километр, а протяжённость линий метрополитена - до 420 км (в настоящее время в Москве около 400 км линий метро, а плотность улично-дорожной сети в 2,5 раза меньше, чем в Большом Париже).

Продолжается тенденция превращение сферы жилищного строительства в финансовый институт долгосрочных инве- стиций, что не сокращает постоянное отставание развития транспортной и инженерной инфраструктур города от темпов жилищного строительства.

В 2005 году правительством Москвы было приняло решение о начале работ по актуализации генерального плана Москвы до 2025 года. Его причинами стали не только окончание срока реализации первой очереди мероприятий генерального плана, но и принятие в конце 2004 года нового Градостроительного кодекса $Р \Phi^{7}$, изменившего требования к составу, порядку разработки, утверждению и реализации генерального

Градостроительный кодекс Российской Федерации» от 29.12.2004 № 190-ФЗ [Электронный ресурс] // Справочно-правовой портал «Консультант Плюс». - Режим доступа: http://www.consultant.ru/document/cons_doc_ LAW_51040/ (дата обращения: 17.08.2019).

Москва.

Архитектурнопланировочная организация города.

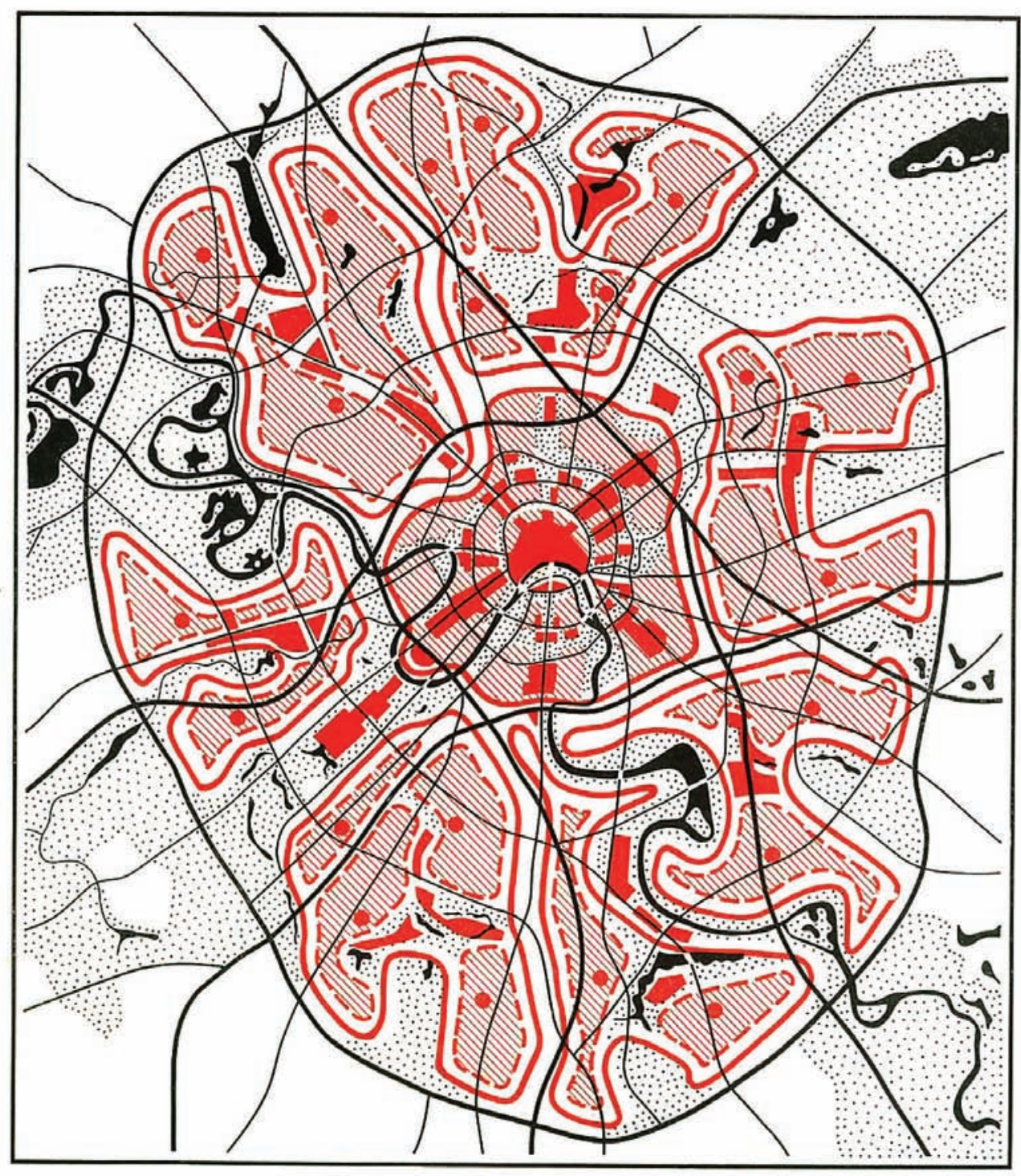

Рис. 14. Генеральный план Москвы. 1971 год [4]

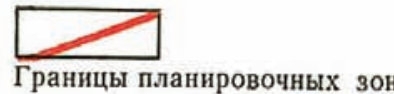

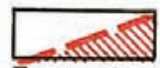

Границы планировочных районов

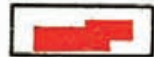

Общегородские

общественные центры

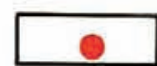

Центры планировочных районов

\section{$\because \because \because \because \because \because$}

Зеленые насаждения общегородского пользования

Схема районной планировки Москвы и области.

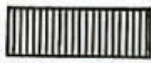

Лесопарковый защитный пояс

\section{(I)}

Пригородная зона Москвы

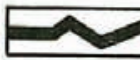

Граница Московской области

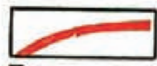

Границы зон влияния городов Московской области

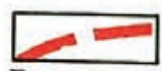

Границы зон влияния городов - областных центров

\begin{tabular}{l}
\hline О \\
Города - производственно- \\
общественные центры \\
местных снстем расселения \\
(О) \\
Города - областные центры
\end{tabular}




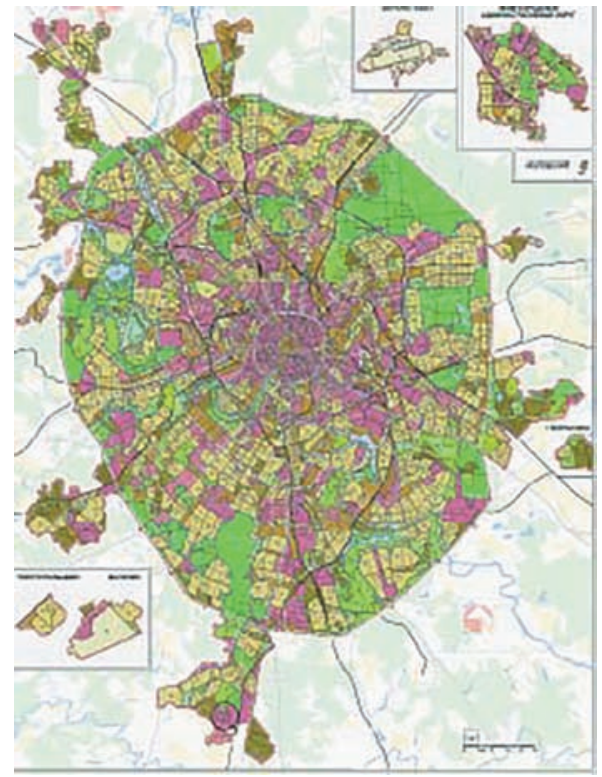

a)

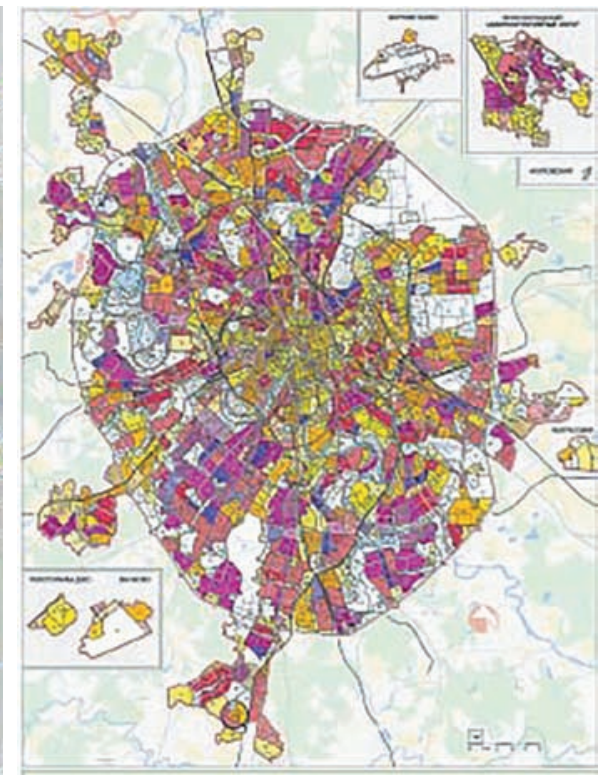

б)

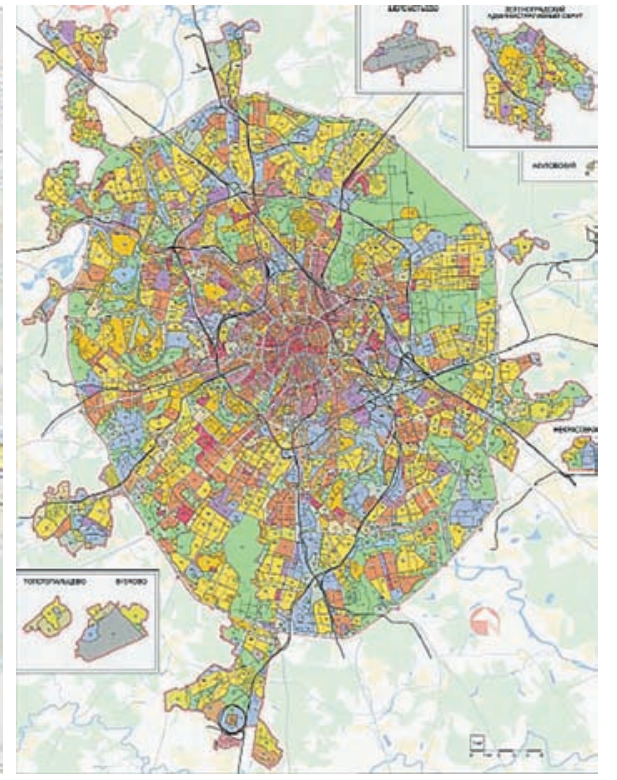

B)

Рис. 15. Генеральный план развития Москвы на период до 2020 года (1999): а) функциональное зонирование; б) строительное зонирование; в) ландшафтное зонирование [4]

плана. Из его состава в самостоятельный документ были выделены градостроительные регламенты - правила землепользования и застройки. А функции генерального плана (рис. 16) ограничились установлением зон планируемого размещения объектов транспорта, инженерной инфраструктуры и социальной сферы, а затем - только перечнем конкретных объектов различного назначения и уровня, без системы целеполагания и ключевых показателей на перспективу.

Таким образом, последующие многочисленные изменения в Градостроительный кодекс РФ, особенно с 2011 года ${ }^{8}$ практически выхолостили содержание генеральных планов, тем самым освободив органы власти от ответственности и обязательств по выполнению ранее утверждённых документов территориального планирования. Однако необходимо напомнить, что генеральный план имеет не только правовой статус, но это всегда и политический документ, который, как в зеркале, отражает отношение к власти.

Формирование и проведение сбалансированной градостроительной политики, основой которой является постоянный мониторинг: непрерывный технологический цикл обоснования, разработки, принятия, контроля реализации и актуализации градостроительных решений на долгосрочную перспективу, - по-прежнему остаётся главным вызовом современности.

\footnotetext{
${ }^{8}$ Федеральный закон от 20.03.2011 № 41-Ф3 «0 внесении изменений в Градостроительный кодекс Российской Федерации и отдельные законодательные акты Российской Федерации в части вопросов территориального планирования» // Справочно-правовая система «Консультант Плюс». URL: http://www. consultant.ru/document/cons_doc_LAW_111777/ (дата обращения: 19.08.2019)
}

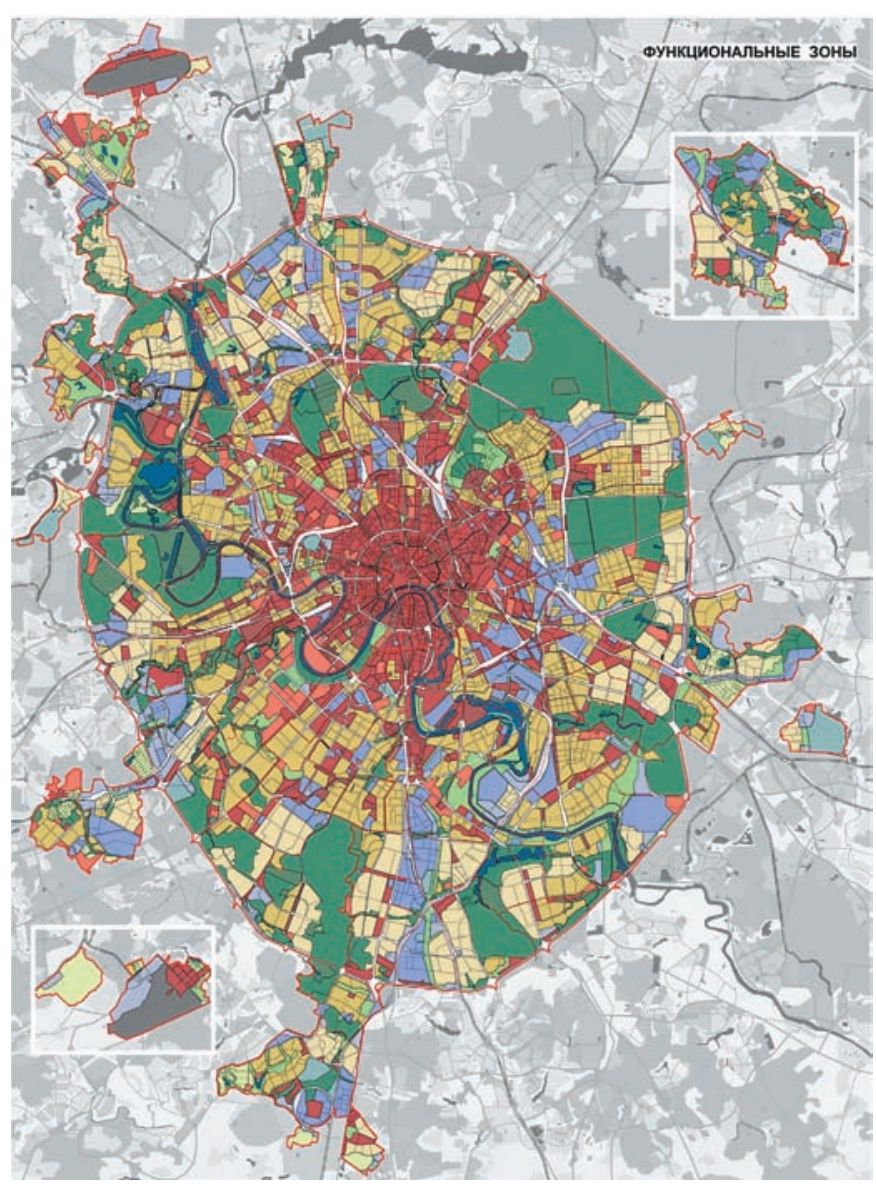

Puс. 16. Генеральный план развития Москвы на период до 2025 года (2010) [4] 


\section{Лuтература}

1. Международные рекомендации по городскому и территориальному планированию (IG-UTP) [Электронный ресурс] // UN HABITAT. - Режим доступа: https://unhabitat. org/books/международные-рекомендации-по-город/) (дата обращения 10.01.2020).

2. Land-use Planning Systems in the OECD. Country Fact Sheets [Электронный ресурс] // OECDiLibray. - Режим доступа: https://doi.org/10.1787/9789264268579-en (дата обращения 3.12.2019).

3. Schéma directeur dela région Ile-de-France [Электронный ресурс] // Région Ile-de-France. - Режим доступа: https:// www.iledefrance.fr/environnement-territoires/construire-lile-de-france-de-2030 (дата обращения 3.12.2019).

4. Москва. Преемственность в переменах. 400 лет градостроительных планов Москвы / Сост. А.Б. Савченко - М. : НИ и ПИ Генплана Москвы, 2013. - 165 с.

5. Буржель, Ги. Умирает ли Париж? / Под общ.ред. В.А. Догадайло; пер. с франц. Е. Туницкой и С. Колесникова. -М. : Дело, 2014. - 176 с.

6. Le plan Prost de Paris [Электронный ресурс]. - Режим доступа: http://e-cours.univ-paris1.fr/modules/uoh/parisbanlieues/u7/co/1-2.html (дата обращения 11.11.2019).

7. Code del'urbanisme [Электронный ресурс] // Legifrance. gouv.fr. - Режим доступа:: https://www.legifrance.gouv.fr/ affichCode.do;jsessionid=D89E16EEC80BB0A6C84BBBCA8F96 0AA7.tplgfr27s_2?idSectionTA=LEGISCTA000031212665\&cidT exte=LEGITEXT000006074075\&dateTexte=20190825 (дата обращения10.11.201).

8. PLU: Paris modifie son Plan local d'urbanisme pour changer la Ville [Электронный ресурс] // Paris. - Режим доступа: https://www.paris.fr/actualites/modification-duplan-local-d-urbanisme-parisien-plu-3879 (дата обращения: 11.08.2019).

9. Le plan local d'urbanisme (PLU) version du 26/07/2019 // Paris. Plan Local d'Urbanisme. - Режим доступа: http:// pluenligne.paris.fr/plu/page/PLU?page_id=1 (дата обращения 1.12.2019).

10. Journal Officiel de la République Française - JORF $n^{\circ} 0128$ du 5 juin 2010 page 10339 texte $n^{\circ} 2010-597$ du 3 juin 2010 relative au Grand Paris/. - Режим доступа: //www.journalofficiel.gouv.fr (дата обращения 11.12.2019).

11. Воронцов А.Р. Взаимосвязанное развитие Московской области и города Москвы: старые вопросы и новые вызовы / А.Р. Воронцов, , А.В. Кузьмин, Л.Я. Ткаченко // Academia. Архитектура и строительство. - 2016. - № 4. - С. 76-81.

12. Москва в цифрах: с начала века до наших дней : Статистический сборник. - М. : Мосгоркомстат, 1997. - 115 с.

13. Градостроительство Москвы: 90-е годы / Под ред. А.В. Кузьмина. - М. : АО «Московские учебники и картолитография», 2000. - 280 c.

14. Кузьмин, А.В. Особенности территориального планирования Большого Лондона и региона Иль-де-Франс /
А.В. Кузьмин, Л.Я. Ткаченко // Academia. Архитектура и строитеьство. - 2012. - № 2. - С. 68-72.

\section{References}

1. Mezhdunarodnye rekomendatsii po gorodskomu $i$ territorial'nomu planirovaniyu (IG-UTP) [nternational recommendations on urban and territorial planning (IGUTP)]. UN HABITAT. - URL: https://unhabitat.org/books/ mezhdunarodnye-rekomendatsii-po-gorod/) (Accessed 10.01.2020).

2. Land-use Planning Systems in the OECD. Country Fact. OECDiLibray. URL: https://doi.org/10.1787/9789264268579-en (Accessed 3.12.2019)

3. Schéma directeur dela région Ile-de-France. Région Ilede-France. URL: https://www.iledefrance.fr/environnementterritoires/construire-l-ile-de-france-de-2030 (Accessed 3.12.2019).

4. Moskva. Preemstvennost' v peremenakh. 400 let gradostroitel'nykh planov Moskvy [Moscow. Continuity in change. 400 years of urban development plans in Moscow]. Moscow, NIiPI Genplana Moskvy Publ., 2013, 165 p.

5. Burzhel', Gi. Umiraet li Parizh? V.A. Dogadailo (ed.). Moscow, Delo Publ, 2014, 176 p.

6. Le plan Prost de Paris. URL: http://e-cours.univ-paris1. $\mathrm{fr} /$ modules/uoh/paris-banlieues/u7/co/1-2.html (Accessed 11.11.2019).

7. Code de l'urbanisme. Legifrance.gouv.fr. URL: https:// www.legifrance.gouv.fr/affichCode.do;jsessionid=D89E16EEC 80BB0A6C84BBBCA8F960AA7.tplgfr27s_2?idSectionTA=LEGIS CTA000031212665\&cidTexte $=$ LEGITEXT000006074075\&dateTe $x t e=20190825$ (Accessed 10.11.201).

8. PLU: Paris modifie son Plan local d'urbanisme pour changer la Ville Paris. URL: https://www.paris.fr/actualites/ modification-du-plan-local-d-urbanisme-parisien-plu-3879 (Accessed 11.08.2019).

9. Le planlocal d'urbanisme (PLU) version du 26/07/2019 // Paris. Plan Local d'Urbanisme. - URL: http://pluenligne.paris. $\mathrm{fr} / \mathrm{plu} /$ page/PLU?page_id=1 (Accessed1.12.2019).

10. Journal Officiel de la République Française - JORF $n^{\circ} 0128$ du 5 juin 2010 page 10339 texte $n^{\circ}$ 2010-597 du 3 juin 2010 relative au Grand Paris/. - URL: //www.journal-officiel. gouv.fr (Accessed11.12.2019).

11. Vorontsov A.R., Kuz'min A.V., Tkachenko L.Ya. Vzaimosvyazannoe razvitie Moskovskoi oblasti i goroda Moskvy: starye voprosy i novye vyzovy [The interconnected development of the Moscow region and the city of Moscow: old questions and new challenges]. Academia. Arkhitektura $i$ stroitel'stvo [Academia. Architecture and construction], 2016, no. 4, pp. 76-81. (In Russ., Abstr. In Engl.)

12. Moskva $v$ tsifrakh: s nachala veka do nashikh dnei : Statisticheskii sbornik [Moscow in numbers: from the beginning of the century to the present day: Statistical collection]. Moscow, Mosgorkomstat Publ., 1997, 115 p 
13. Gradostroitel'stvo Moskvy: 90-e gody [Urban Planning of Moscow: 90s]. A.V. Kuzmin (ed.). Moscow, «Moskovskie uchebniki i kartolitografiya» Publ., 2000, 280 p.

14. Kuz'min, A.V. Tkachenko L.Ya. Osobennosti territorial'nogo planirovaniya Bol'shogo Londona i regiona Il'-de-Frans [Features of territorial planning of Greater London and the Ile-de-France region]. Academia. Arkhitektura i stroitel'stvo. [Academia. Architecture and construction], 2012, no. 2, pp. 68-72. (In Russ., Abstr. In Engl.)

Кузьмин Александр Викторович, 1951-2019. (Москва), академик РААСН. Президент РААСН (2014-2019).

Ткаченко Людмила Яковлевна (Москва). Кандидат географических наук, советник РААСН. Советник директора ГАУ МО «НИиПИ градостроительства» (129110, Москва, ул. Гиляровского, 47, стр. 3. нИиПИ градостроительства). Эл.почта: mila/tkachenko@ mail.ru.

Kuzmin Alexander Viktorovich, 1951-2019. (Moscow), Academician of RAACS. President of RAACS (2014-2019).

Tkachenko Lyudmila Yakovlevna (Moscow). Candidate of Geographical Sciences, Advisor of RAACS. Advisor to the Director of the Research and Design Institute of Urban Planning (47 Gilyarovskogo St, b. 3, Moscow, 129110. NIiPI). E-mail: mila/tkachenko@ mail.ru. 